\title{
Local Knowledge of Dayak Tomun Lamandau About the Honey Harvest
}

\author{
Brian L. Djumaty \\ Antakusuma University \\ Pangkalan Bun, Indonesia \\ Brian.djumaty@gmail.com
}

\begin{abstract}
Culture is the result of a set of experiences provided by nature. like the local knowledge to harvest honey by society Tomun Lamandau, Central Borneo. This research uses descriptive qualitative method and data collection techniques including observation, interviews, and documentation. The results showed that society already have knowledge about protecting nature in a way as not to damage the honeycomb and tree. Some of the equipment used to harvest the honey has been modified.
\end{abstract}

Keywords: Local Knowledge, Dayaknese, Protecting Nature Introduction

\section{INTRODUCTION}

Based on data from the Central Statistics Agency (BPS) in 2010, there are more than 300 ethnic groups or tribes 1.340 or more than 300 ethnic groups. The diversity of the culture of each region in Indonesia has a characteristic, as well as local values that is unique [1]. Similarly, the Dayak community. Based on the book Cultural Arts and Heritage Indonesia [2], natives of the island of Borneo as many as 200 tribes. According [3], the Dayak population as a whole consists of 405 tribes and has a different regional languages. Dayak community also has many local traditions are loaded with the values of indigenous people who have been handed down by our ancestors until now.

In line with the thinking Riwut, Marzali said that culture generated an experience of predecessors through the process of interacting with nature, and preserve and pass on their local culture to the next generation [4]. Likewise, the local knowledge possessed by the Society Tomun Lamandau, Lamandau Regency, Central Kalimantan Province. Local communities have local knowledge in harvesting honey that has been handed down by our ancestors. Over time, changes have occurred related to the process of harvesting the honey Dayak Tomun Lamandau. These changes are related to the equipment used to harvest the honey, although in the process of implementation of the honey harvest people still carry out traditional ritual procession.

Based on the above presentation of this research focuses on 1) How Community Dayak Tomun Lamandau maintain the existence of the honey harvest in the perspective of their local knowledge? 2) What equipment modifications made by Community Dayak Tomun Lamandau harvesting honey?

\section{RESEARCH METHODOLOGY}

\section{A. Research Approach}

In this study the authors used a qualitative approach. Qualitative methods using data collected by interviews, field observations and documents [5]. This type of research is descriptive. Descriptive Aiming to describe accurately the characteristics and focus on the fundamental question of "How" for trying to acquire and convey the facts clearly and accurately [6]. The goal is to describe accurately the characteristics of a phenomenon or problem studied so as to convey the facts clearly and accurately [7].

\section{B. Research Field}

This research was carried out starting from a survey of student placement Field Work Experience (KKN) Antakusuma University in Kabupatan Lamandau. Writer fascinated by the culture of the local community. One of them is the knowledge of local communities to harvest the honey.

This research was conducted in June-August 2016. The research location is in District Lamandau, Menthobi Raya subdistrict. To get to the location of the research, researchers used a two-wheeled motorcycle from the town of Pangkalan Bun West Kotawaringin with three-hour journey. To go to the district Menthobi highway authors must pass through winding roads and damaged

\section{RESEARCH FINDINGS \& DISCUSSION}

Local wisdom of the Dayak Tomun Lamandau the honey harvest is inseparable from the philosophy of the community as part of the indigenous community is still very dependent on nature [8]. Based on the findings in the field, the author will discuss two important points in order to answer the formulation of research problems, are;

\section{A. Existence of Local Knowledge Harvesting Honey}

The persistence of local community knowledge about the harvest honey is inseparable from the dynamics experienced by indigenous peoples and the role of actors in maintaining the existence of knowledge harvest honey.

1. The dynamics of indigenous peoples

Challenges that occur and experienced by the community of Dayak Tomun Lamandau associated with maintaining their local knowledge to harvest the honey is the inclusion of modernization, so the impact on regional development remains focused on economic development. Changes considered is the number of indigenous community lands by the government converted into oil palm plantations and industrial forest planting (HTI). where many indigenous lands were turned into oil palm plantations belonging to both personal and corporate and 
pulpwood plantations were planted acacia trees, eucalyptus and tree Jabon (raw material of paper).

In addition to the land use change, change that is felt by indigenous peoples is their culture shift the impact of the influx of culture from the outside (the impact of the transmigration), and changes in livelihoods. In ancient times the people who are in Sub Menthobi Raya is still the traditional farmers where dependence on forests and forest products become very large. Interactions between human society and nature are mutually beneficial interactions. This is consistent with the philosophy of the community of Dayak Tomun Lamandau especially in Sub Menthobi Raya.

The biggest challenge is perceived by the indigenous peoples concerned foreign investors also have an impact on their local knowledge on how to harvest honey. Indigenous territories that had been preserved as one of the natural honey-producing areas to be disturbed where the area harvested and planted with acacia trees. But because of the strong social capital owned by indigenous people, allowing them to retain one of the trees (trees ketapang) which is usually a wild honey taken.

In keeping ketapang tree, choose one of the leaders of society to maintain and oversee the procession harvest honey. The figures generally been customary to represent indigenous peoples with unlimited working life or during these figures can still be trusted as an indigenous representative.

\section{The role of actor}

Based on the findings in the field, there are two actors who are very instrumental in managing and maintaining the system of local knowledge about harvesting honey, namely (a). Manter adat/ ketua adat. Manter adat position as the indigenous leaders makes it have absolute power to represent the voice of indigenous peoples. Through this manter adat indigenous peoples define indigenous representatives to keep the tree where the bees usually make honey. One characteristic of representatives of indigenous actor was someone who could be trusted and have a good social capital (b) Wakil adat is one of the traditional leaders designated to maintain, manage and harvest honey. In performing its duties, customs representatives are legally protected customary. There are unwritten prohibitions apply, where in addition to the indigenous representatives should not be anyone harvest honey, sell or can enjoy the honey. If there is a violation in addition to customary fine imposed will also be brought to the normative law.

\section{B. Modification Honey Harvesting Equipment}

In the present context, the many changes that occur in the process of harvesting the honey. Changes are very visible is the change in the tools used to harvest the honey. Although there is a change in some of the equipment used but in ritual procession harvest honey still retain the customary procession, which has been passed down from generation to ancestors.
Some equipment changes are a bucket, rope and a squeeze of honey.

Local knowledge possessed by the people is the result of the interaction between humans and nature.

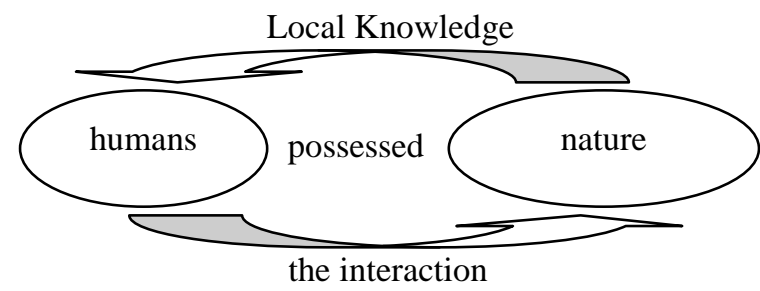

In the diagram, can be explained that the process of local knowledge for their interaction with nature that has been providing community needs to survive so that the formation of local knowledge.

Once upon a time the environment is still providing the equipment needed by the community to harvest the honey. However, upon the entry of modernization and globalization in Indonesia, especially in Central Kalimantan availability of some of the equipment is difficult to find. Here's a diagram.

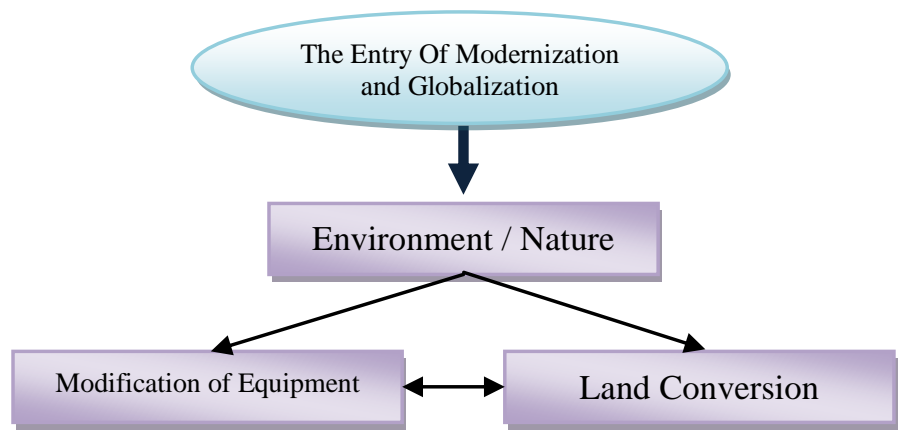

Diagram 1.2 the impact of modernization and globalization

The diagram above shows that the implication behind the inclusion of modernization and globalization in Indonesia especially specifically in Central Kalimantan will affect the environment and natural surroundings (the equipment provider for the community to harvest the honey). Ironically again is going over the land from forest to oil palm plantations, mining etc. Data from the Central Kalimantan Wahli shows that the forest area of 15.3 million and 12.7 million herkat herktar controlled by invester and have been converted. Based on these data we can say that sisah forest in Central Kalimantan 2.6 million hectares and so far in 2016 is still going on land and forest fires in Central Kalimantan. 


\section{The process of Honey Harvest}

When have known honeycomb honey has had, according to the knowledge society, it will be harvest. Based on the local community calendar, the harvest is carried out must see the moonlight. People believe that when there is light then the bees will attack. On this basis so that the harvest should be put on the schedule. Schedule used is six kolapan in the language of Dayak Tomun Lamandau. This means that the harvest process begins when it is dark for up to six hours ahead. Why six hours? Because people assume when the harvest is only carried out one to two hours maximum yields and honey not only would disturb a beehive, but it also will have an impact on the quality of honey that will be generated in the future.

Before climbing the tree should burn tebai community to bloat under the tree should be done a few hours before harvesting activities. There are some restrictions that cannot be uttered by the people who will climb trees like calling a name. No designation should be used as from young to old, and vice versa. In addition there is a ritual in which people who want to climb shall drink tuak and read a few words of prayer. The meaning of all taboos and rituals that must be done is that they are not stung by a bee when to harvest the honey.

Within a year the public can harvest honey two to three times. In the process of harvesting the honey are the division of tasks. Two people served as climbing and four people waiting to be taken in order to do the tree separating honey from the hive. After honeycomb lowered to the ground, then society separates pure nest and the nest is still there wasps / bees child.

Communities can distinguish the quality of the honey produced. When committed extortion no wasps / child waton on it, then the quality is good (quality number one), then when there is a child wasps when squeezed, the quality is number two. In harvest honey usually must be followed by representatives of indigenous because without the presence of representatives of indigenous then the honey should not be harvested. After completion of harvest honey usually indigenous representatives will share the honey harvest in accordance with the levels, such as indigenous peoples represented by manter adat will have the number one quality honey. Usually indigenous people will get the honey evenly. Then wakil adat and climbers will get the honey quality number two. Agreement on dividing the harvest of honey has also been governed by custom.

\section{Equipment used}

Here are some of the tools used in the process of harvesting the honey Dayak Tomun Lamandau, namely;

\section{Making Stairs On Trees Ketapang}

Ketapan tree is a tree where the bees produce honey normally. Ketapan tree is a tree that is very high, so the harvest honey in the community must make a ladder that will be used to climb the tree. Here's a picture ketapan tree and stairs made of ironwood (iron wood);

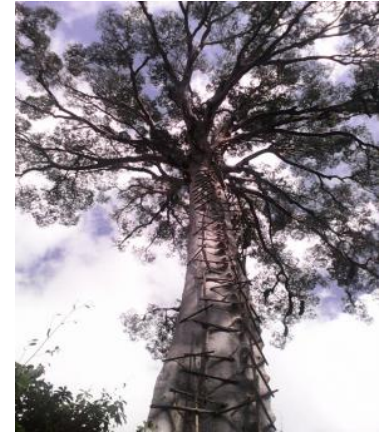

(data source : Personal Documents, 2016)

Picture 1.1 Tangga untuk memanen madu

From these images there are stairs that used to take honey. The basic ingredients are used as the stairs are wooden Ulin (iron wood). Based on the interview, the reason for choosing ironwood is because wood is a type of wood that is strong and can withstand any conditions such as rainy season or dry season. ulian an original wood timber from Kalimantan scattered in the forests. The process of installing ladders done at night. Here is an interview with Mr. Artemon excerpt

\section{Wood ulian is native of Borneo. Wood is not only used as a ladder but, fences, roofs walls, boats etc. Ironwood pemasagan The process of carried out at night. This is done so the bees do not attack (cpc Artemon).}

In the process of harvesting the honey, manufacture of stairs from ironwood is only done the first time hendsak harvest only. If the existing stairs of iron wood then there will be no process of making the stairs again. Typically the manufacturing ladder to be used to harvest the honey, made for approximately one month. Not everyone can make a ladder dipohon ketapan. In the making of this ladder only those who have believed and agreed upon by custom who can do it.

\section{Tebai}

The basic ingredients of tebai is the root of the tree. The process of of which is Cut to size, beaten (cracked), dried in the sun for three days, smoked for three hours and tied up. The function of Tebai is as a tool to repel wasps from the nest. Usually tebai end will be burned later placed under the tree so that the smoke rising close ketapang beehive.

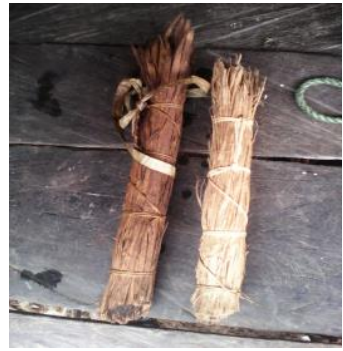

(data source : Personal Documents, 2016) Picture 1.2 tebai 


\section{Buckets and ropes}

Ropes used as a media liaison between the climber with the guard who had been waiting to be taken to lower the honeycomb tree that has been incorporated into a bucket. When completed the new nest is derived from the tree, there is a place for extortion.

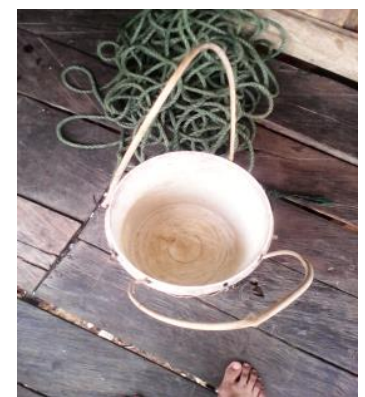

(data source : Personal Documents, 2016)

\section{Gambar 1.3 ember dan tali}

\section{The squeeze honey}

Points squeeze honey made from tarpaulin. In ancient times a squeeze of honey is made from the bark of trees, because of the scarcity of the tree bark then the public anticipate with tarpaulins.

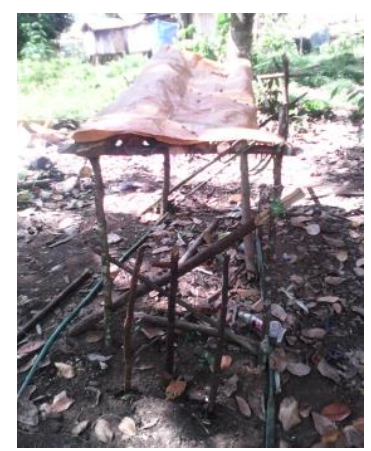

(data source : Personal Documents, 2016)

Picture 1.4 tempat memeras madu

\section{CONCLUSION}

1. Indigenous peoples retain their local knowledge to harvest the honey is supported by customary institutions are still strong. Where manter adat and wakil adat become a very important point. The role of social capital wakil adat also be a dominant element.

2. Modification of the equipment used is a form of strategy of indigenous peoples in maintaining their local knowledge to harvest honey.

\section{ACKNOWLEDGMENT}

The author would like to thank the Foundation Kotawaringin Antakusuma University, Rector of the Antakusuma University, Lamandau District Government for financial support.

\section{REFERENCES}

[1] Hasmah. "Fishermen Local Knowledge Systems in Marine Resource Management Ujung Lero Pinrang". Journals Walasuji. Volume 5. No. 2. December 2014

[2] Turangan, L. W, and R. Fadhila. "Arts Culture And Heritage Indonesia: Human And Environmental Culture". Volume 7. Jakarta: PT. Aku Bisa; 2014

[3] Dey, Nina Putri Hayam, "Rite Manuba Ba Adat: Practical Ecology Control Dayak Tomun Lamandau of Batu Tunggal village in Central Borneo".Satya Wacana University Press. Salatiga; 2015

[4] Marzali, Amri. "Anthropology and Development Indonesia". First Edition. third printing. Jakarta : Kencana. 2009

[5] Raco, J R. " Metode Penelitian Kualitatif : Jenis, Karakteristik, dan keunggulannya ". Jakarta. Grasindo; 2010

[6] Silalahi, Ulber. "metode penelitian sosial". bandung: PT Refika Aditama; 2012

[7] Silalahi, Ulber. "Social Research Methods". Bandung: PT Refika Aditama; 2012

[8] Dey, Nina Putri Hayam, "Rite Manuba Ba Adat: Practical Ecology Control Dayak Tomun Lamandau of Batu Tunggal village in Central Borneo".Satya Wacana $\begin{array}{llr}\text { University } & \text { Press. } & \text { Salatiga; }\end{array}$ 